\title{
AMETHOPTERIN (METHOTREXATE) IN CONNECTIVE TISSUE DISEASE-PSORIASIS AND POLYARTHRITIS
}

\author{
BY \\ G. D. KERSLEY \\ Bath
}

Methotrexate (amethorterin), a folic acid reductase inhibitor, affects primarily the tissues that are growing most rapidly. When in prolonged contact with the cell, its interference with the supply of available folic acid reduces the DNH content and hence holds up preparation for mitosis and division. Apart from neoplastic cells, the rapid epidermal proliferation of psoriasis is particularly susceptible; after this the brunt of the attack falls on the endothelium of the oral mucosa and gastro-intestinal tract, the hair follicles, and later the blood-forming elements - especially the granulocytes. The drug is easily absorbed orally and the greater part is excreted in the urine within 12 hours. Impaired renal function potentiates its effect, pregnancy is a contraindication, and over-dosage should be treated with folinic acid (Leucovorin).

Folic acid antagonists were first used in the treatment of psoriasis by Gubner, August, and Ginsberg (1951). Further reports on their use in this disease were made by Rees, Bennett, Hamlin, and Maibach (1964), and Ryan, Vickers, Salem, Callender, and Badenoch (1964), three deaths being reported by the former. Shrank and Blendis (1965) gave details of two cases in which methotrexate at least contributed to death, one from leucopenia and the other from duodenal haemorrhage. O'Brien, Van Scott, Black, Eisen, and Bunim (1962) reported sixteen cases of psoriatic arthritis, two of psoriasis and arthritis, and five of rheumatoid arthritis treated with parenteral methotrexate $25 \mathrm{mg}$. every 7 to 14 days. In thirteen of these eighteen cases the joints and the skin condition showed some improvement, but eleven developed anorexia, five leucopenia, and one alopecia. In all cases the toxic reactions subsided within 2 weeks of ceasing treatment.

Recently Haim, and Alroy (1967) reported deaths after 5 and 7 days respectively of $5.0 \mathrm{mg}$. methotrexate, plus steroids, apparently from leucopenia and sepsis. Burrows and Kelly (1967) recorded severetoxicity and leucopenia with recovery in 3 weeksos after taking only $2 \cdot 5 \mathrm{mg}$. for 4 days.

\section{Present Investigations}

A case of severe pustular psoriatic arthritis reacted so well to methotrexate, relapsing when theo drug was stopped and improving again when it was restarted, that further investigation of its effecte both on the psoriasis and arthritis was prompted.0

\section{Case Report}

A man aged 52 years noticed stiffness after exercise at the age of 30 and had an attack of bilateral sciatica at age 37.0 In March, 1964, at the age of 48, he developed simul- $\frac{0}{0}$ taneously severe psoriasis and arthritis of the right elbow and left shoulder.

When seen in August, 1964, he had a very severe $\overline{3}$ generalized psoriasis, pustular psoriasis of the fingernailsand toenails, and extremely swollen and partly sub-o luxated knees and ankles. The neck and back were stiff but there was little pain. He had lost a stone in weight and his temperature rose to $101^{\circ} \mathrm{F}$. at night. The erythro-cyte sedimentation rate was $120 \mathrm{~mm}$. $/ \mathrm{hr}$., $\mathrm{Hb} 70$ per cent. and rheumatoid factor tests negative.

He was immediately given ACTH 40 units daily, erythromycin, and imferon injections. The results were most disappointing, the haemoglobin dropping to 60 응 per cent. The white count was $5,000 / \mathrm{cu}$. mm. with 78 per $>$ cent. polymorphs. He was transfused with packed red을. cells, and prednisolone rising to $15 \mathrm{mg}$./day was added, yet by November he was extremely ill. He was then giveno $4 \mathrm{mg}$. betamethasone (Betnesol), equivalent to approxi- $N$ mately $35 \mathrm{mg}$. prednisolone, plus $2.5 \mathrm{mg}$. methotrexate on 5 days per week, and the ACTH was stopped. Improve- $\omega$ ment was dramatic and the medication was continued for 7 months, with very gradual reduction of the betamethato sone to $2 \mathrm{mg}$., until June, 1965.

The patient was now a changed man. The erythrocyte? sedimentation rate had fallen from 80 to $2 \mathrm{~mm}$./hr., the $\mathrm{Hb}$ was 104 per cent., and the white cell count hadō changed from 8,800 to $6,400 / \mathrm{cu}$. mm. He had, however, 
gained too much weight and was walking with sticks. The psoriasis was well controlled and all infection had disappeared. The only trouble during the period had been a collapsed vertebra in February, 1965, which was treated satisfactorily with durabolin, calcium, a high protein diet, and (temporarily) a back support.

In the next 5 months the methotrexate was discontinued, but the Betnesol $2 \mathrm{mg}$. daily was maintained. At the end of this period both the arthritis and the psoriasis were again much worse and methotrexate $2.5 \mathrm{mg}$. daily was restarted with no other change in medication. Both joints and psoriasis again improved dramatically and in May, 1966, he was in very good condition except that the haemoglobin had risen to 122 per cent. The erythrocyte sedimentation rate was $2 \mathrm{~mm}$./hr., and the white blood count $7,200 / \mathrm{cu}$. mm. P32 was administered and the haemoglobin dropped to 102 per cent.

The methotrexate was then discontinued again, but by July, 1966, the psoriasis was again a serious problem and he has since been given methotrexate $2.5 \mathrm{mg}$. 3 days a week with continued good results.

In view of this patient's excellent progress, methotrexate has been tried in twelve other patients, including ten with psoriatic arthritis. The clinical results are summarized in the Table.

Seven of the ten cases of psoriasis showed a dramatic improvement in their skin lesions and one some benefit. In five of twelve cases the arthritis appeared to benefit greatly and in one there was some improvement. Only five, however, were completely free of toxic symptoms; the other seven all developed mouth ulcers. One also had diarrhoea and vomiting and one complained of loss of hair. In all cases the onset of toxic symptoms occurred within 7 days of starting treatment, but they all disappeared within a month of discontinuing the drug and in most cases within 10 days. In all cases regular complete blood counts were carried out and it is a striking fact that in no case was there any evidence of depression of red or white cell formation. Even during severe toxic reactions the only change in the white count was an occasional slight leucocytosis.

\section{Summary and Conclusion}

Ten cases of psoriatic polyarthritis and two other cases were treated with methotrexate. The psoriasis was improved in 80 per cent. and the joints in 50 per cent. Ulceration of the mouth occurred in 58 per cent. of those treated. None showed evidence of haemopoietic damage.

These results indicate that the frequency of toxic reactions and likely length of remission of symptoms is such that amethopterin is not suitable for routine use. Certain patients, however, tolerate the drug well and it may be valuable under careful supervision in selected severe cases of psoriatic arthritis.

TABLE

EFFECT OF METHOTREXATE IN TWELVE CASES

\begin{tabular}{|c|c|c|c|c|c|c|c|c|c|}
\hline \multirow{2}{*}{$\begin{array}{l}\text { Case } \\
\text { No. }\end{array}$} & \multirow{2}{*}{ Diagnosis } & \multicolumn{2}{|c|}{ First Course } & \multirow{2}{*}{$\begin{array}{l}\text { Interval } \\
\text { (if any) } \\
\text { in } \\
\text { Months }\end{array}$} & \multicolumn{2}{|c|}{ Second Course } & \multirow{2}{*}{$\begin{array}{c}\text { Toxic } \\
\text { Reaction } \\
\text { and } \\
\text { Duration }\end{array}$} & \multicolumn{2}{|c|}{ Effect } \\
\hline & & $\begin{array}{c}\text { Average Dose } \\
\text { mg./day }\end{array}$ & $\underset{(w k s)}{\text { Duration }}$ & & $\begin{array}{c}\text { Average Dose } \\
\text { (mg./day) }\end{array}$ & $\begin{array}{c}\text { Duration } \\
\text { (wks) }\end{array}$ & & On Psoriasis & On Joints \\
\hline 1 & Psoriatic & $1 \cdot 8$ & 30 & 5 & $1 \cdot 8$ & 26 & Nil & Good & Good \\
\hline 2 & $\begin{array}{l}\text { Psoriatic } \\
\text { Arthritis }\end{array}$ & $2 \cdot 5$ & 3 & 0 & $5 \cdot 0$ & 6 & $\begin{array}{l}\text { Rash and mouth } \\
\text { ulcers } \\
10 \text { days } \\
\text { Fever }\end{array}$ & Good & Good \\
\hline 3 & $\begin{array}{l}\text { Psoriatic } \\
\text { Arthritis }\end{array}$ & $2 \cdot 5$ & 3 & 0 & $5 \cdot 0$ & 1 & $\begin{array}{l}\text { Mouth ulcers } \\
\text { and sore throat } \\
4 \text { weeks }\end{array}$ & Good & None \\
\hline 4 & $\begin{array}{l}\text { Psoriatic } \\
\text { Arthritis }\end{array}$ & & 2 & 1 & $2 \cdot 5$ & $0 \cdot 5$ & $\begin{array}{l}\text { Slight mouth } \\
\text { ulceration }\end{array}$ & Good & Good \\
\hline 5 & $\begin{array}{l}\text { Psoriatic } \\
\text { Arthritis }\end{array}$ & $2 \cdot 5$ & 8 & & & & $\begin{array}{l}\text { Slight mouth } \\
\text { ulceration }\end{array}$ & Good & Good \\
\hline 6 & $\begin{array}{l}\text { Psoriatic } \\
\text { Arthritis }\end{array}$ & $2 \cdot 5$ & 5 & 2 & $2 \cdot 5$ & 5 & $\begin{array}{l}\text { Loss of halr } \\
\text { Nil }\end{array}$ & $\begin{array}{c}\text { Slight } \\
\text { improvement }\end{array}$ & $\begin{array}{c}\text { Slight } \\
\text { improvement }\end{array}$ \\
\hline 7 & Psoriatic & $5 \cdot 0$ & 3 & 0 & $2 \cdot 5$ & 8 & $\mathrm{Nil}$ & Good & None \\
\hline 8 & Psoriatic & $2 \cdot 5$ & 2 & 0 & $5 \cdot 0$ & 10 & Nil & Good & Good \\
\hline 9 & $\begin{array}{l}\text { Arthritis } \\
\text { Psoriat:c } \\
\text { Arthritis }\end{array}$ & $5 \cdot 0$ & 8 & 1 & $5 \cdot 0$ & 3 & Nil & Good & Good \\
\hline 10 & $\begin{array}{l}\text { Psoriatic } \\
\text { Arthritis }\end{array}$ & $5 \cdot 0$ & 1 & & & & $\begin{array}{l}\text { Ulcerated mouth } \\
\text { Fever }\end{array}$ & None & None \\
\hline 11 & $\begin{array}{l}\text { Rheumatoid } \\
\text { Arthritis }\end{array}$ & $2 \cdot 5$ & 1 & 0 & $5 \cdot 0$ & $0 \cdot 5$ & $\begin{array}{l}\text { Rash } \\
\text { Ulcerated mouth } \\
\text { Diarrhoea and } \\
\text { vomiting }\end{array}$ & - & None \\
\hline 12 & $\begin{array}{l}\text { Systemic Lupus } \\
\text { Erythematosus }\end{array}$ & $2 \cdot 5$ & 7 & & & & Nil & - & None \\
\hline
\end{tabular}


The experience of Burrows and Kelly (1967) and of Haim and Alroy (1967) and the results in two of our patients (Cases 10 and 11) suggest that some

persons are unduly sensitive to methotrexate; others, however, react extremely well to this drug even when used for a prolonged period (Cases 1 and 9).

\section{REFERENCES}

Burrows, D., and Kelly, A. (1967). Lancet, 1, 1383 (Methotrexate in psoriasis).

Gubner, R., August, S., and Ginsberg, V. (1951). Amer. J. med. Sci., 221, 176 (Therapeutic suppression of tissue reactivity).

Haim, S., and Alroy, G. (1967). Lancet, 1, 1165 (Methotrexate in psoriasis).

O'Brien, W. M., Van Scott, E. J., Black, R. L., Eisen, A. Z., Bunim, J. J. (1962). Arthr. and Rheum., 5, 312 (Clinical trial of amethopterin (Methotrexate) in psoriatic and rheumatoid arthritis).

Rees, R. B., Bennett, J. H., Hamlin, E. M., and Maibach, H. I. (1964). Arch. Derm. (Chicago), 90, 544 (Aminopterin for psoriasis).

Ryan, T. J., Vickers, H. R., Salem, S. N., Callender, S. T., and Badenoch, J. (1964). Brit. J. Derm., 76, 555 (The treatment of psoriasis with folic acid antagonists).

Shrank, A. B., and Blendis, L. M. (1965). Brit. med. J., 2, 156 (Folic acid antagonists in treatment of psoriasis).

L'améthoptérine (Méthotrexate) dans les maladies du tissu conjonctif-psoriasis et polyarthrite

\section{RÉSUMÉ}

On traita par le Méthotrexate dix cas de polyarthrite psoriasique et deux autres cas. Le psoriasis régressa dans $80 \%$ des cas et l'atteinte articulaire dans $50 \%$. Des ulcérations buccales apparurent dans $58 \%$ des cas traités. On n'observa pas de signes d'atteinte hématopoiétique.

Ces résultats montrent que la fréquence des réactions toxiques et la durée probable de régression des symptômes est telle que ce produit n'est pas à conseiller comme traitement régulier. Toutefois, certains malades tolèrent bien ce médicament et il pourrait être d'un grand secours dans des cas graves sélectionnés d'arthrite psoriasique.

L'expérience de Burrows et Kelly (1967) et de Haim et Alroy (1967) et les résultats obtenus chez deux de nos malades (cas 10 et 11) suggèrent que certains sujets sont particulièrement sensibles au Méthotrexate; d'autres cependant réagissent extrêmement bien à ce médicament, même utilisé pour un traitement prolongé (cas 1 et 9).
Ametopterina (Methotrexate) en las enfermedades delo tejido conectivo - psoríasis y poliartritis

\section{SUMARIO}

Se trataron con Methotrerate diez casos de poliartritis psoriásica y dos otros casos. La psoriasis mejoró en un₹ $80 \%$ de los casos y la afección articular en un $50 \%$. Ulceraciones orales sobrevinieron en un 58 de los casose tratados. No se observaron signos de afección hemaf-@ poyética.

Estos resultados muestran que la frecuencia đeo reacciones tóxicas y la duración probable de la regresiôn sintomática son tales que este producto no se puede aconsejar para un tratamiento regular. Sin embargo, ciertos enfermos le toleran bien y en casos graves y cuidadosamente escogidos su empleo pueder ser util.

La experiencia de Burrows y Kelly (1967) y la de Haim $\overrightarrow{\overrightarrow{0}}$ y Alroy (1967) y los resultados obtenidos con dos enfer-윽 mos nuestros (casos 10 y 11) sugieren que algunos sujetosson particularmente sensibles a Methotrerate; otros, sin embargo, lo aguantan muy bien y a veces durante un. tratamiento prolongado (casos 1 y 9 ). 